\title{
ЕКОНОМІКА
}

УДК 331.5(477)

DOI: https://doi.org/10.26642/jen-2021-4(98)-3-9

\author{
Л.С. Лісогор, д.е.н., проф. \\ Національний інститут стратегічних досліджень \\ Н.В. Руденко, к.е.н., доц. \\ Київський національний університет імені Тараса Шевченка
}

\section{Оцінка структурних змін зайнятості на регіональних ринках праці}

Проблеми структурних зрушень у сфері зайнятості регіонів в умовах інноваційних змін потребують детального дослідження та набувають особливої актуальності, оскільки саме підвищення освітнього рівня населення регіонів забезпечує можливості реалізачії їх освітнього потенціалу. Дослідження структурних змін зайнятості населення регіонів (за рівнями освіти) дало змогу визначити напрями адаптаџіï сфери зайнятості до інноваційних змін. Оцінювання інтенсивності структурних змін зайнятості населення регіонів (за рівнями освіти) свідчить про збереження високих коефіиієнтів «абсолютних» структурних зрушень у регіонах зі значною часткою висококваліфікованих прачівників у структурі зайнятих. Визначено причини збереження невисоких темпів структурних зрушень зайнятості працівників з вищою освітою в окремих регіонах, зокрема, посилення міграційних відтоків робочої сили з праценадлишкових регіонів, обмежені можливості працевлаштування за професією, з належним рівнем оплати праці. Обтрунтовано, щзо регіони, в яких коефіцієнти «абсолютних» структурних зрушень зайнятості працівників з вищою освітою перевищують середній рівень, більи привабливі з позицій можливостей їх працевлаштування та забезпечення професійного розвитку у перспективі. Здійснене групування регіонів за розподілом коефіцієнтів «абсолютних» структурних зрушень серед зайнятого населення з вищою освітою дало змогу визначити інтенсивність змін залежно від рівня економічного розвитку регіону, розвиненості освітньоі мережі та інновачійної інфраструктури. 3 метою забезпечення можливостей реалізації освітнього потенціалу регіонів за рахунок підвищення освітнього рівня населення запропоновано залучати роботодавців до розробки освітніх програм; розвивати систему дуальної освіти. Також обтрунтовано необхідність сприяння розвитку неформальної освіти, що підвищуватиме рівень конкурентоспроможності робочої сили; створення умов для розбудови системи підтвердження результатів неформальної освіти за рахунок розширення мережі кваліфікаційних центрів. Розвиток системи освіти та професійної підготовки на регіональному рівні потребує запровадження моніторингу розвитку регіональних ринків праці та збалансування попиту й пропозиції на ринку праці (за рівнями освіти).

Ключові слова: освітній рівень; освітній потенціал регіонів; інтенсивність структурних зрушень; конкурентоспроможність фахівців; структурні зміни зайнятості.

Актуальність теми. Підвищення конкурентоспроможності національних економік в умовах глобалізаційних змін може бути забезпечено на основі ефективного формування та розвитку людського капіталу. Досягнення поставлених цілей передбачає необхідність забезпечення інноваційних змін зайнятості за рахунок покращення якості освітнього потенціалу населення. Однак в умовах зростання обсягів міграційного відтоку кваліфікованої робочої сили, погіршення якості освітніх послуг, можливості реалізації освітнього потенціалу для забезпечення інноваційних змін зайнятості населення як окремих регіонів, так і країни значно обмежуються. Відповідно для активізації інноваційних чинників розвитку економіки країни необхідне забезпечення структурних змін зайнятості за рахунок реалізації освітнього потенціалу на національному та регіональному рівнях. Саме тому особливої актуальності в сучасних умовах набувають питання оцінювання структурних змін зайнятості (залежно від рівня освіти населення) на регіональних ринках праці, що сприятиме ефективній реалізації освітнього потенціалу для збалансування попиту та пропозиції.

Аналіз останніх досліджень та публікацій засвідчив, що переважна більшість наукових праць присвячена дослідженню питань трансформації структури зайнятості населення на національному та регіональному рівнях; аналізу проблем структурних змін зайнятості в умовах інноваційних змін. Теоретичним та методологічним проблемам трансформації структури зайнятості населення в умовах інноваційних змін присвячено наукові праці Р.Р. Баглей [1], В.В. Близнюк [2], Т.В. Бучинської [1], Л.М. Ільїч [5], І.Л. Петрової [9], Т.В. Романової [12], І.О. Штундер [14], Я.І. Юрик [2] та ін. Зокрема, аналізуючи кількісні та якісні наслідки трансформації структури ринку праці, змісту та характеру праці під впливом постіндустріалізації, Л.М. Ільїч підкреслювала об'єктивну необхідність зростання попиту на висококваліфіковану робочу силу, збільшення інвестицій в освіту, накопичення якісних характеристик людських ресурсів [5, с. 115]. Серед зарубіжних дослідників проблем структурних змін зайнятості, які 
відбуваються під впливом технологічних змін, варто виокремити В.С. Гімпельсона [3], Л.С. Казинця [6], P.I. Капелюшникова [7], М.Павелеску [15]. Згідно з точкою зору Р.І. Капелюшникова, під впливом технологічного прогресу трансформуються не тільки рівень, але й структура попиту на робочу силу: нові технології починають пред’являти більш високі вимоги до рівня освіти та кваліфікації працівників [7]. Відповідно пріоритетного значення для обслуговування високотехнологічного устаткування набувають освітньо-кваліфікаційні характеристики працівників. Однак дотепер недостатньо дослідженими залишаються питання оцінювання інтенсивності структурних змін зайнятості населення регіонів (за рівнями освіти), необхідних для визначення напрямів адаптації сфери зайнятості до інноваційних змін за рахунок підвищення освітньо-кваліфікаційного рівня робочої сили.

Метою статті $є$ дослідження структурних змін зайнятості населення регіонів (за рівнями освіти), оцінювання інтенсивності структурних зрушень та визначення напрямів адаптації сфери зайнятості до інноваційних змін. До завдань дослідження варто зарахувати систематизацію чинників впливу на інтенсивність структурних змін зайнятості (за рівнями освіти), що сприятиме більш ефективній реалізації освітнього потенціалу регіонів.

Викладення основного матеріалу. Отримання конкурентних переваг національними економіками в умовах глобалізації відбувається за рахунок мобілізації інноваційних чинників розвитку, покращення якості робочої сили, здатної генерувати та впроваджувати інновації. Структурні зміни в економіці, які відбуваються під впливом інноваційних змін, передбачають необхідність систематичного оновлення виробничих потужностей, поступову заміну застарілих технологій, автоматизацію виробництва та запровадження сучасних форм організації виробництва та праці. Водночас вплив процесу реструктуризації економіки на сферу зайнятості характеризується трансформацією структури попиту на робочу силу. Це проявляється через поступове скорочення потреби у масових професіях за одночасного зростання попиту на кваліфікованих працівників, що володіють сучасними знаннями та характеризуються високим ступенем готовності до роботи в умовах інноваційних змін.

Сприяння адаптивності працівників до структурних зрушень ринку праці, на думку науковців Національного інституту стратегічних досліджень, передбачає розвиток професійної освіти, стимулювання роботодавців до створення та підтримки ефективної системи професійного розвитку персоналу на виробництві, а працівників - до зміни кваліфікації робочої сили та набуття навичок відповідно до нових вимог [13, с. 246]. Ринок праці поступово розпочинає набувати т. зв. «дуальних ознак», які проявляються через збільшення потреби у кваліфікованих працівниках, здатних творчо, креативно виконувати поставлені завдання, та поступове скорочення потреби у робітниках, залучених до виконання регламентованих, чітко визначених операцій з обслуговування машин та устаткування.

ля забезпечення адаптованості працівників до структурних змін на ринку праці, набуття навичок та компетентностей для підвищення рівня конкурентоспроможності необхідно посилення їх готовності до постійного оновлення знань та професійного розвитку. Освіта та професійна підготовка в сучасних умовах формують основу конкурентоспроможності фахівця, забезпечують змістовну підтримку виникнення інновацій у сфері праці та реалізацію можливостей продукування нових ідей [8, с. 142]. Відповідно оцінювання інтенсивності структурних змін зайнятості населення регіонів (за рівнями освіти) сприятиме визначенню можливостей підвищення конкурентоспроможності робочої сили за рахунок покращення якості їі освітньо-кваліфікаційних характеристик в умовах інноваційних змін.

Для оцінювання структурних змін зайнятості науковці використовують підхід Л.С. Казинця, згідно 3 яким розраховується квадратичний коефіцієнт «абсолютних» структурних зрушень (на основі коефіцієнта середнього квадратичного відхилення), який відображає відсоткову динаміку відхилення часток структурних елементів один від одного протягом визначеного періоду часу. Формула квадратичного коефіцієнта «абсолютних» структурних зрушень може бути наведена у вигляді:

$$
K_{i}=\sqrt{\sum \frac{\left(d_{i j}-d_{i j-1}\right)^{2}}{n}}
$$

де $K_{i}-$ квадратичний коефіцієнт «абсолютних» структурних зрушень;

$d_{i j}$ - частка $i$-го елемента структури зайнятих у $j$-й період;

$d_{i j-1}$ - частка $i$-го елемента структури зайнятих у період, який передує $j$-му періоду;

$n$ - кількість градацій у структурі зайнятих [6, с. 154].

За шкалою оцінювання структурних зрушень найвищим рівнем інтенсивності змін часток зайнятих (за окремими структурними компонентами) характеризуються показники, які вирізняються більш високим значенням квадратичного коефіцієнта «абсолютних» структурних зрушень. При цьому найбільш значний розмах варіації характерний для показників, що відображають зміни структури зайнятості населення за регіонами, обумовлені нерівномірністю розподілу інноваційно активних підприємств, темпів технологічного оновлення за регіонами тощо.

Аналіз розподілу зайнятого населення регіонів України (за рівнями освіти) протягом останніх років свідчить про збереження значної регіональної диференціації. Водночас сфери зайнятості окремих 
регіонів по-різному реагували на поширення кризових явищ в економіці країни в результаті нерівномірності розподілу економічного потенціалу та негативного впливу пандемії COVID-19. Разом 3 тим, необхідно враховувати, що освітня структура зайнятості достатньо інертно реагує на швидкі кон'юнктурні зміни, оскільки трансформації відбуваються з певним часовим лагом.

Результати аналізу змін часток зайнятих (за рівнями освіти) протягом 2018-2020 рр., представлені у таблиці 1, свідчать про збереження достатньо високих коефіцієнтів «абсолютних» структурних зрушень у регіонах, в яких значно зберігається частка висококваліфікованих працівників. Зокрема сфера зайнятості тих регіонів, які характеризувалися превалюванням у структурі робочої сили працівників 3 високим рівнем освіти та кваліфікації, найменшою мірою реагувала на коливання інтенсивності структурних змін зайнятості (за рівнями освіти). Традиційно найбільшою часткою населення 3 вищою освітою в освітній структурі зайнятого населення регіонів відзначалися економічно розвинені регіони (зокрема, Дніпропетровська, Київська, Львівська області) та м. Київ.

Таблиия 1

Динаміка змін часток зайнятих (за рівнями освіти) у регіональному розрізі, 2018-2020 рр.

\begin{tabular}{|c|c|c|c|c|c|c|c|c|}
\hline \multirow{3}{*}{ Область } & \multicolumn{8}{|c|}{ Зміни частки зайнятих за рівнями освіти: } \\
\hline & \multicolumn{2}{|c|}{ повна вища освіта } & \multicolumn{2}{|c|}{$\begin{array}{c}\text { базова та неповна } \\
\text { вища освіта }\end{array}$} & \multicolumn{2}{|c|}{$\begin{array}{c}\text { професійно- } \\
\text { технічна освіта }\end{array}$} & \multicolumn{2}{|c|}{$\begin{array}{c}\text { повна, загальна та } \\
\text { базова середня освіта }\end{array}$} \\
\hline & $\begin{array}{c}\text { \% 2019) - } \\
\%(2018) \\
\left(d_{i j-1}\right)\end{array}$ & $\begin{array}{c}\%(2020)- \\
\%(2019) \\
\left(d_{i j}\right)\end{array}$ & $\begin{array}{c}\%_{(2019)}- \\
\%(2018) \\
\left(d_{i j-1}\right)\end{array}$ & $\begin{array}{c}\%(2020)- \\
\%(2019) \\
\left(d_{i j}\right)\end{array}$ & $\begin{array}{c}\%(2019)- \\
\%(2018) \\
\left(d_{i j-1}\right)\end{array}$ & $\begin{array}{c}\%(2020)- \\
\%(2019) \\
\left(d_{i j}\right)\end{array}$ & $\begin{array}{c}\%(2019)- \\
\%(2018) \\
\left(d_{i j-1}\right)\end{array}$ & $\begin{array}{c}\%(2020)- \\
\%(2019) \\
\left(d_{i j}\right)\end{array}$ \\
\hline Вінницька & $-0,2$ & 0,1 & 0,3 & $-0,4$ & 0,2 & 0,1 & $-0,6$ & 0,2 \\
\hline Волинська & 0,1 & 0,0 & $-0,5$ & 0,1 & 0,4 & $-0,1$ & $-0,5$ & 0,0 \\
\hline Дніпропетровська & 0,4 & 0,3 & 1,0 & $-0,1$ & $-0,5$ & $-0,2$ & $-1,0$ & 0,2 \\
\hline Донецька & $-0,4$ & $-0,2$ & 0,5 & 0,1 & 0,0 & 0,0 & $-1,5$ & 0,1 \\
\hline Житомирська & 0,0 & 0,0 & $-0,4$ & 0,1 & $-0,3$ & 0,0 & 0,4 & $-0,3$ \\
\hline Закарпатська & $-0,1$ & 0,0 & $-0,4$ & 0,1 & $-0,2$ & 0,1 & 0,9 & $-0,1$ \\
\hline Запорізька & $-0,3$ & $-0,1$ & $-0,4$ & $-0,1$ & 0,0 & 0,0 & 0,6 & 0,0 \\
\hline Івано-Франківська & 0,1 & $-0,1$ & $-0,2$ & $-0,2$ & 0,2 & 0,3 & 0,1 & $-0,1$ \\
\hline Київська & 0,3 & 0,2 & 0,3 & $-0,3$ & 0,7 & $-0,1$ & $-1,1$ & 0,7 \\
\hline Кіровоградська & $-0,1$ & 0,0 & $-0,1$ & 0,0 & $-0,1$ & $-0,1$ & $-0,1$ & $-0,1$ \\
\hline Луганська & 0,1 & $-0,1$ & $-0,4$ & $-0,2$ & 0,0 & 0,2 & $-0,4$ & 0,0 \\
\hline Львівська & 0,2 & 0,1 & 0,0 & 0,2 & 0,3 & $-0,1$ & $-0,1$ & $-0,1$ \\
\hline Миколаївська & $-0,1$ & $-0,1$ & 0,0 & $-0,1$ & $-0,1$ & 0,1 & 0,0 & 0,1 \\
\hline Одеська & 0,0 & $-0,1$ & 1,4 & 0,0 & $-0,2$ & 0,4 & 0,0 & 0,0 \\
\hline Полтавська & 0,3 & $-0,2$ & $-1,0$ & 0,2 & $-0,5$ & 0,2 & 0,7 & $-0,2$ \\
\hline Рівненська & 0,3 & $-0,1$ & 0,0 & 0,0 & $-0,3$ & 0,1 & 0,1 & $-0,1$ \\
\hline Сумська & 0,6 & 0,1 & $-0,4$ & 0,2 & $-0,2$ & $-0,3$ & $-0,3$ & $-0,3$ \\
\hline Тернопільська & $-0,5$ & $-0,1$ & 0,1 & 0,0 & 0,4 & 0,0 & $-0,1$ & 0,1 \\
\hline Харківська & $-0,6$ & $-0,4$ & 1,0 & 0,7 & 0,8 & $-0,4$ & 0,0 & 0,3 \\
\hline Херсонська & $-0,1$ & 0,0 & $-0,1$ & 0,1 & $-0,3$ & $-0,1$ & 0,5 & 0,0 \\
\hline Хмельницька & $-0,1$ & 0,1 & $-0,1$ & 0,1 & $-0,2$ & $-0,2$ & 0,6 & $-0,1$ \\
\hline Черкаська & 0,0 & 0,0 & 0,2 & $-0,2$ & $-0,3$ & 0,1 & $-0,1$ & $-0,2$ \\
\hline Чернівецька & $-0,4$ & 0,0 & $-0,4$ & $-0,1$ & 0,3 & 0,0 & 1,2 & 0,2 \\
\hline Чернігівська & $-0,1$ & 0,0 & $-0,5$ & 0,0 & 0,3 & $-0,1$ & 0,1 & $-0,1$ \\
\hline м. Київ & 0,8 & 0,6 & 0,2 & $-0,2$ & $-0,6$ & 0,0 & 0,6 & $-0,1$ \\
\hline
\end{tabular}

Джерело: розраховано авторами на основі даних вибіркового обстеження економічної активності населення України $[4,10,11]$. Примітка: $d_{i j-1}$ - частка $i$-го елемента структури зайнятих у період, який передує $j$-му періоду;

$d_{i j}$ - частка $i$-го елемента структури зайнятих у $j$-й період

Натомість найбільш динамічними позитивними змінами часток зайнятих з базовою та неповною вищою освітою характеризувалися такі регіони, як Харківська, Одеська, Донецька, Львівська області. Однак у переважній більшості регіонів спостерігалася або стагнація, або зниження часток зайнятих 3 базовою та неповною вищою освітою. Водночас у сегменті зайнятих 3 професійно-технічною освітою відбувалися достатньо суттєві зміни, які значною мірою визначалися економічною спеціалізацією регіону, з одного боку, та розвиненістю мережі закладів професійної (професійно-технічної) освіти, 3 іншого боку. Зокрема позитивну динаміку змін часток зайнятих 3 професійно-технічною освітою демонстрували Івано-Франківська, Луганська, Одеська, Полтавська, Рівненська та Закарпатська області.

Для більш детального дослідження регіонального розподілу структурних зрушень зайнятості населення (залежно від рівнів освіти) доцільно проаналізувати варіацію коефіцієнтів «абсолютних» структурних зрушень серед зайнятих (за рівнями освіти). Результати аналізу, які наведено у таблиці 2 , 
свідчать, що найбільш високі значення коефіцієнтів «абсолютних» структурних зрушень (серед зайнятих 3 повною вищою освітою) спостерігалися у м. Києві $(0,477)$, Харківській $(0,348)$, Сумській областях $(0,303)$, тоді як найнижчі значення коефіцієнтів зазначалися у Житомирській $(0,006)$, Черкаській $(0,018)$ областях. Відповідно найнижчі значення коефіцієнтів характеризують невисоку інтенсивність структурних зрушень зайнятості (у сегменті вищої освіти), яка проявляється через поступове зниження частки зайнятих з вищою освітою у загальній кількості зайнятого населення. Серед найважливіших причин збереження невисоких коефіцієнтів «абсолютних» структурних зрушень зайнятості працівників 3 вищою освітою можливо вирізнити, передусім, посилення міграційних відтоків робочої сили 3 праценадлишкових регіонів як результат відсутності можливостей працевлаштування за професією, 3 належним рівнем оплати праці. Натомість регіони, в яких коефіцієнти «абсолютних» структурних зрушень зайнятих працівників 3 вищою освітою перевищують середній рівень, можуть бути найбільш привабливими 3 позицій можливостей працевлаштування та забезпечення професійного розвитку у перспективі.

Таблиця 2

Регіональний розподіл коефіиієнтів «абсолютних» структурних зрушень серед зайнятих (за рівнями освіти)

\begin{tabular}{|c|c|c|c|c|c|c|c|c|}
\hline \multirow{3}{*}{ Область } & \multicolumn{8}{|c|}{ Рівні освіти } \\
\hline & \multicolumn{2}{|c|}{ повна вища } & \multicolumn{2}{|c|}{$\begin{array}{c}\text { базова та неповна } \\
\text { вища } \\
\end{array}$} & \multicolumn{2}{|c|}{$\begin{array}{c}\text { професійно- } \\
\text { технічна }\end{array}$} & \multicolumn{2}{|c|}{$\begin{array}{c}\text { повна, загальна та } \\
\text { базова середня }\end{array}$} \\
\hline & $\left(d_{i j}-d_{i j-1}\right)^{2}$ & $K_{i}$ & $\left(d_{i j}-d_{i j-1}\right)^{2}$ & $K_{i}$ & $\left(d_{i j}-d_{i j-1}\right)^{2}$ & $K_{i}$ & $\left(d_{i j}-d_{i j-1}\right)^{2}$ & $K_{i}$ \\
\hline Вінницька & 0,076 & 0,138 & 0,232 & 0,241 & 0,051 & 0,113 & 0,342 & 0,292 \\
\hline Волинська & 0,022 & 0,074 & 0,214 & 0,231 & 0,195 & 0,221 & 0,282 & 0,266 \\
\hline Дніпропетровська & 0,241 & 0,246 & 1,070 & 0,517 & 0,325 & 0,285 & 1,048 & 0,512 \\
\hline Донецька & 0,237 & 0,244 & 0,252 & 0,251 & 0,001 & 0,013 & 2,176 & 0,738 \\
\hline Житомирська & 0,000 & 0,006 & 0,131 & 0,181 & 0,093 & 0,153 & 0,252 & 0,251 \\
\hline Закарпатська & 0,004 & 0,032 & 0,199 & 0,223 & 0,052 & 0,114 & 0,770 & 0,439 \\
\hline Запорізька & 0,100 & 0,158 & 0,186 & 0,216 & 0,003 & 0,026 & 0,395 & 0,314 \\
\hline Івано-Франківська & 0,011 & 0,053 & 0,068 & 0,130 & 0,130 & 0,181 & 0,030 & 0,087 \\
\hline Київська & 0,156 & 0,198 & 0,215 & 0,232 & 0,548 & 0,370 & 1,637 & 0,640 \\
\hline Кіровоградська & 0,017 & 0,065 & 0,007 & 0,043 & 0,019 & 0,069 & 0,008 & 0,045 \\
\hline Луганська & 0,029 & 0,085 & 0,223 & 0,236 & 0,043 & 0,104 & 0,151 & 0,194 \\
\hline Львівська & 0,055 & 0,117 & 0,035 & 0,094 & 0,082 & 0,143 & 0,028 & 0,084 \\
\hline Миколаївська & 0,011 & 0,053 & 0,004 & 0,033 & 0,026 & 0,080 & 0,014 & 0,058 \\
\hline Одеська & 0,008 & 0,046 & 1,844 & 0,679 & 0,197 & 0,222 & 0,001 & 0,015 \\
\hline Полтавська & 0,144 & 0,190 & 1,000 & 0,500 & 0,332 & 0,288 & 0,560 & 0,374 \\
\hline Рівненська & 0,068 & 0,130 & 0,003 & 0,026 & 0,089 & 0,149 & 0,019 & 0,068 \\
\hline Сумська & 0,368 & 0,303 & 0,183 & 0,214 & 0,113 & 0,168 & 0,222 & 0,236 \\
\hline Тернопільська & 0,264 & 0,257 & 0,008 & 0,045 & 0,190 & 0,218 & 0,007 & 0,042 \\
\hline Харківська & 0,486 & 0,348 & 1,364 & 0,584 & 0,865 & 0,465 & 0,070 & 0,132 \\
\hline Херсонська & 0,013 & 0,058 & 0,008 & 0,046 & 0,078 & 0,139 & 0,205 & 0,226 \\
\hline Хмельницька & 0,025 & 0,079 & 0,010 & 0,049 & 0,070 & 0,132 & 0,350 & 0,296 \\
\hline Черкаська & 0,001 & 0,018 & 0,084 & 0,145 & 0,092 & 0,152 & 0,045 & 0,106 \\
\hline Чернівецька & 0,192 & 0,219 & 0,192 & 0,219 & 0,085 & 0,145 & 1,465 & 0,605 \\
\hline Чернігівська & 0,017 & 0,065 & 0,302 & 0,275 & 0,100 & 0,158 & 1,465 & 0,605 \\
\hline м. Київ & 0,912 & 0,477 & 0,092 & 0,151 & 0,360 & 0,300 & 0,009 & 0,049 \\
\hline
\end{tabular}

Джерело: розраховано авторами на основі даних вибіркового обстеження економічної активності населення України [4, 10, 11].

Примітка: $\left(d_{i j}-d_{i j-1}\right)^{2}-$ квадрат змін частки $i$-го елемента структури зайнятих у $j$-й період, та частки $i$-го елемента структури зайнятих у період, який передує $j$-му періоду; $K_{i}$ - коефіцієнти «абсолютних» структурних зрушень

Водночас достатньо значущою є регіональна диференціація коефіцієнтів «абсолютних» структурних зрушень (серед зайнятих з базовою та неповною вищою освітою), що відображає значний регіональний розмах варіації за цим показником. Зокрема, найвищі показники були зафіксовані в Одеській $(0,679)$, Харківській $(0,584)$ та Дніпропетровській $(0,517)$ областях; натомість найнижчі показники відзначалися у Рівненській $(0,026)$, Миколаївській $(0,033)$ та Кіровоградській $(0,043)$ областях. Це свідчить про нерівномірність змін часток зайнятих з базовою та неповною вищою освітою за регіонами протягом останніх років, що є результатом збереження певних диспропорцій розподілу освітнього потенціалу за регіонами, з одного боку, та суттєвої диференціації обсягів потреби у робочій силі (за видами економічної діяльності, професіями та рівнями освіти), з іншого боку.

Аналіз диференціації регіонів за коефіцієнтами «абсолютних» структурних зрушень (серед зайнятих 3 професійно-технічною освітою) свідчить про існування значного розриву між регіонами, що $\epsilon$ 
результатом нерівномірності міжрегіонального розподілу виробничого потенціалу, недостатньо ефективно розвиненої інфраструктурної мережі закладів професійної (професійно-технічної) освіти за регіонами. Найвищі коефіцієнти структурних зрушень спостерігалися у Харківській $(0,465)$, Київській $(0,370)$ областях та місті Києві $(0,300)$, що певною мірою відображає розподіл існуючих робочих місць, який сформувався, передусім, в результаті економічної спеціалізації регіонів.

Водночас концентрація галузей 3 низькою органічною будовою капіталу, що характеризується високою часткою живої праці в доданій вартості, може призводити до стрімкого зниження частки кваліфікованих працівників в окремих регіонах за одночасного збільшення частки допоміжних робітників, які мають невисокий рівень кваліфікації. Відповідно значна регіональна варіація коефіцієнтів «абсолютних» структурних зрушень характерна також для сфери зайнятості працівників 3 повною, загальною та базовою середньою освітою.

Однак у сучасних умовах найбільш суттєво на реалізацію освітнього потенціалу регіону впливають трансформаційні зміни у структурі зайнятого населення 3 вищою освітою. На думку переважної більшості науковців, структурні та секторальні зміни, які відбуваються під впливом глобалізаційних та технологічних процесів, призводять до змін у структурі та характері зайнятості, умовах праці, організаційних формах суспільно-трудових відносин та потребують притоку нової кваліфікованої робочої сили, здатної оволодівати новими навичками, підвищувати кваліфікаційний рівень та перманентно навчатися [1]. Передусім це стосується працівників 3 вищою освітою, які мають більш високий рівень конкурентоспроможності та здатність до систематичного підвищення рівня кваліфікації й оновлення знань. Саме тому для визначення можливостей реалізації освітнього потенціалу регіону доцільно здійснити групування регіонів за розподілом коефіцієнтів «абсолютних» структурних зрушень серед зайнятого населення з вищою освітою (рис. 1).

Результати групування регіонів за розподілом коефіцієнтів «абсолютних» структурних зрушень зайнятості населення 3 вищою освітою свідчать про достатньо високу інтенсивність змін, що відбувалися, передусім, в економічно розвинених регіонах, які характеризуються збереженням значного потенціалу економічного розвитку, розвиненістю освітньої мережі та інноваційної інфраструктури. Відповідно це може забезпечувати можливості реструктуризації зайнятості у напрямі покращення якості освітнього потенціалу регіонів за рахунок поступового збільшення частки осіб з вищою освітою, здатних більш гнучко адаптуватися до інноваційних змін, у загальній кількості зайнятого населення. Водночас забезпечення ефективної реалізації потенціалу економічного зростання регіонів за рахунок підвищення освітнього рівня зайнятого населення потребує посилення уваги до проблем якості освітніх послуг, посилення мотивації населення до систематичного підвищення кваліфікаційного рівня.

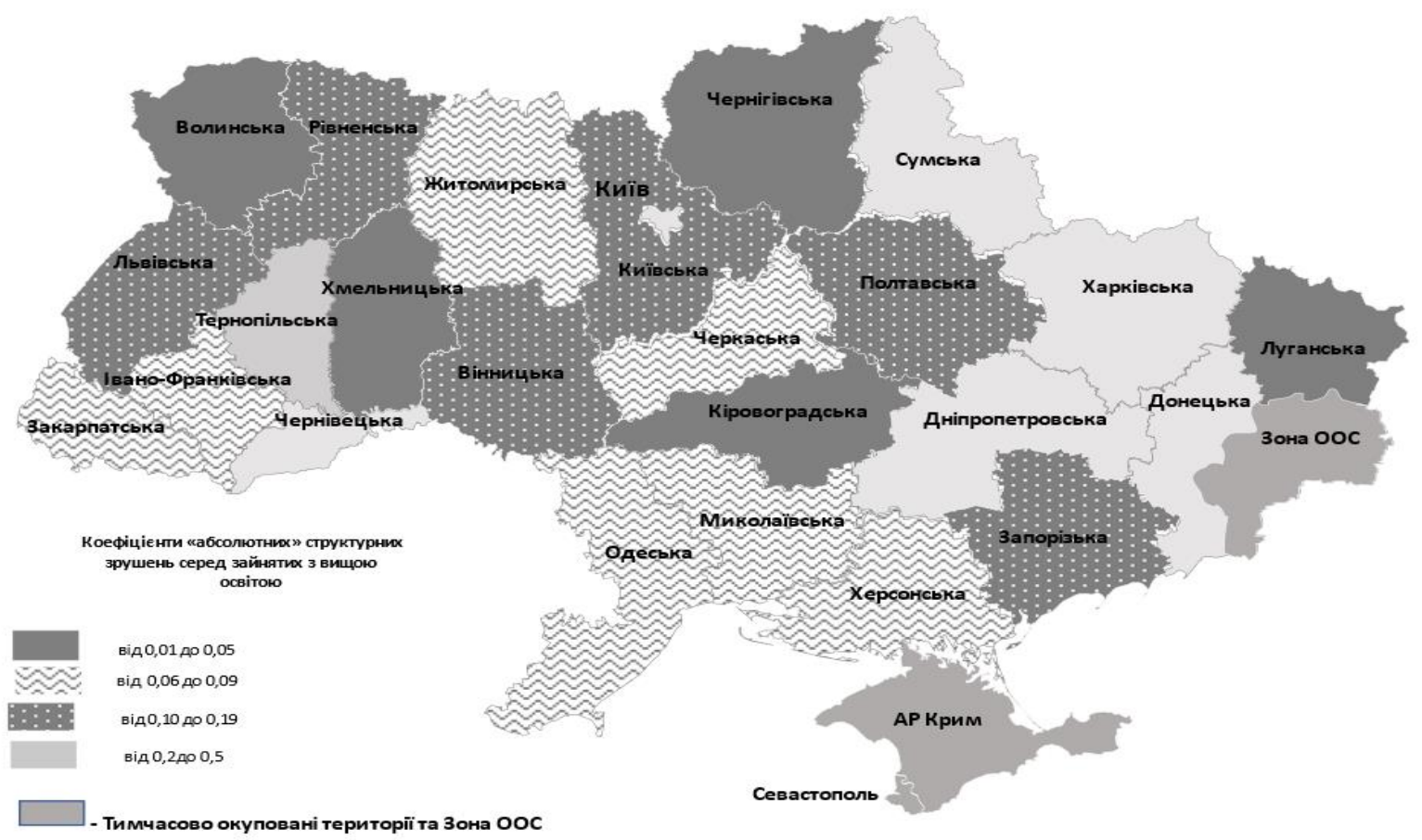

Рис. 1. Групування регіонів за розподілом коефіцієнтів «абсолютних» структурних зрушень (зайняте населення з вищзою освітою) 
В умовах глобалізаційних змін саме освіта, професійна підготовка та професійний розвиток стають найважливішими складовими забезпечення продуктивної та високоефективної зайнятості, покращення якості трудового потенціалу регіонів та країни у цілому. Підвищення освітнього рівня робочої сили значною мірою сприяє отриманню стійких конкурентних переваг, забезпеченню можливостей створення та впровадження інновацій для забезпечення сталого розвитку регіонів.

Саме тому для забезпечення можливостей реалізації освітнього потенціалу регіонів за рахунок підвищення освітнього рівня населення доцільно:

- покращувати якість освітніх послуг за рахунок посилення практико орієнтованого змісту освіти; залучення роботодавців до розробки освітніх програм та освітніх стандартів; забезпечення можливостей стажування студентів та викладачів закладів освіти на виробництві, розбудови системи дуальної освіти;

- сприяти розвитку неформальної освіти, що підвищуватиме рівень конкурентоспроможності фахівців; створювати умови для розбудови системи підтвердження результатів неформальної освіти за рахунок розширення мережі кваліфікаційних центрів;

- підвищувати рівень поінформованості представників регіональних рад професійно-технічної освіти щодо стану розвитку регіонального ринку праці, залучати до участі в освітніх програмах управлінців вищої та середньої ланки органів місцевого самоврядування; стимулювати роботодавців - ключових регіональних стейкхолдерів до систематичного підвищення рівня кваліфікації працівників;

- запровадження моніторингу розвитку регіональних ринків праці (на систематичній основі) для збалансування попиту та пропозиції на ринку праці (за рівнями освіти).

Висновки та перспективи подальших досліджень. Аналіз диференціації регіонів за коефіцієнтами «абсолютних» структурних зрушень (за рівнями освіти) забезпечив можливість здійснити їх групування за інтенсивністю змін структури зайнятого населення залежно від рівня освіти, визначити проблеми та напрями реалізації освітнього потенціалу регіонів за рахунок покращення освітньо-кваліфікаційних характеристик робочої сили. Подальші дослідження тенденцій змін освітньої структури зайнятого населення за регіонами дозволять визначити найбільш ефективні шляхи адаптації сфери зайнятості регіонів до інноваційних змін.

\section{Список використаної літератури:}

1. Баглей P.P. Аналіз трансформації світового ринку праці під впливом революції 4.0 / Р.P. Баглей, T.В. Бучинська // Інноваційна економіка. - 2019. - № 1-2 (78). - С. 5-12.

2. Близнюк В.В. Освітньо-кваліфікаційні диспропорції регіонального ринку праці України / В.В. Близнюк, Я.І. Юрик // Економіка і прогнозування. - 2019. - № 2. - С. 101-119.

3. Гимпельсон B.E. Отраслевые сдвиги и межотраслевое неравенство / В.E. Гимпельсон // Журнал Новой экономической ассоциации. - 2016. - № 3. - С. 186-197.

4. Економічна активність населення України у 2018 р. : статистичний збірник / Державна служба статистики України. - 2019 [Електронний ресурс]. - Режим доступу : http://www.ukrstat.gov.ua/druk/publicat/kat_u/2019/zb/07/zb_EAN_2018.rar.

5. Ільїч Л.М. Структурні трансформації транзитивного ринку праці України : монографія / Л.М. Ільїч. - К. : Алерта, 2017. - $608 \mathrm{c}$.

6. Казинеи Л.С. Измерение структурных сдвигов в экономике / Л.С. Казинец. - М. : Экономика, 1969. - 167 с.

7. Капелюшников Р.И. Технологический прогресс - пожиратель рабочих мест / Р.И. Капелюшников // Вопросы экономики. - 2017. - № 11. - С. 4-17.

8. Людський розвиток в Україні. Інноваційні види зайнятості та перспективи їх розвитку : монографія / за ред. E.M. Лібанової. - К. : Ін-т демографії та соціальних досліджень ім. М.В. Птухи НАН України, 2016. - 328 с.

9. Петрова І.Л. Інноваційний сегмент ринку праці: оцінка тенденцій та перспектив / I.Л. Петрова // Демографія та соціальна економіка. - 2018. - № 1 (32). - С. 166-180.

10. Робоча сила України 2020 : статистичний збірник / Державна служба статистики України. - 2021

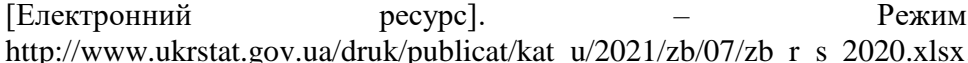

11. Робоча сила України 2019 : статистичний збірник / Державна служба статистики України. - 2020 [Електронний pecypc]. http://www.ukrstat.gov.ua/druk/publicat/kat_u/2020/zb/07/zb_r_s_2019.pdf.

12. Романова T.B. Інтегральні показники оцінювання структурних зрушень в економіці / T.В. Романова // Економіка і регіон. - 2016. - № 6 (61). - С. 20-27.

13. Україна після коронакризи: шлях одужання / Я.А. Жаліло, Я.Б. Базилюк, С.В. Ковалівська та ін. - Київ : НІСД, 2020. - 304 с. [Електронний ресурс]. - Режим доступу : https://niss.gov.ua/sites/default/files/202011/ukraina-pislya-koronakrizi_sait.pdf.

14. Штундер I.O. Ефективна зайнятість: реалії та інноваційні перспективи : монографія / І.О. Штундер. Київ : Університет економіки та права «КРОК», 2016. - 392 с.

15. Pavelescu F.M. Methodological considerations on the size of Coefficient of Intensity of Structural Changes / F.M. Pavelescu // Revista Română de Statistică. - 2014. - Vol. 62 (2). - P. 95-107 [Electronic resource]. - Access mode : https://ideas.repec.org/a/rsr/journl/v62y2014i2p95-107.html\#download. 


\section{References:}

1. Baglej, R.R. and Buchyns'ka, T.V. (2019), «Analiz transformacii' svitovogo rynku praci pid vplyvom revoljucii' 4.0», Innovacijna ekonomika, No. 1-2 (78), pp. 5-12.

2. Blyznjuk, V.V. and Juryk, Ja.I. (2019), «Osvitn'o-kvalifikacijni dysproporcii' regional'nogo rynku praci Ukrai'ny», Ekonomika i prognozuvannja, No. 2, pp. 101-119.

3. Gimpel'son, V.E. (2016), «Otraslevye sdvigi i mezhotraslevoe neravenstvo», Zhurnal Novoi ekonomicheskoi assotsiatsii, No. 3, pp. 186-197.

4. Derzhavna sluzhba statystyky Ukrai'ny (2019), Ekonomichna aktyvnist' naselennja Ukrai'ny u 2018 r., statystychnyj zbirnyk, [Online], available at: http://www.ukrstat.gov.ua/druk/publicat/kat_u/2019/zb/07/zb_EAN_2018.rar

5. Il'i'ch, L.M. (2017), Strukturni transformacii' tranzytyvnogo rynku praci Ukrai'ny, monografija, Alerta, K., 608 p.

6. Kazinets, L.S. (1969), Izmerenie strukturnykh sdvigov v ekonomike, Ekonomika, M., 167 p.

7. Kapelyushnikov, R.I. (2017), «Tekhnologicheskii progress - pozhiratel' rabochikh mest», Voprosy ekonomiki, No. 11, pp. 4-17.

8. Libanovoi', E.M. (ed.) (2016), Ljuds'kyj rozvytok v Ukrai'ni. Innovacijni vydy zajnjatosti ta perspektyvy i'h rozvytku, monografija, In-t demografii' ta social'nyh doslidzhen' im. M.V. Ptuhy NAN Ukrai'ny, K., 328 p.

9. Petrova, I.L. (2018), «Innovacijnyj segment rynku praci: ocinka tendencij ta perspektyv», Demografija ta social'na ekonomika, No. 1 (32), pp. 166-180.

10. Derzhavna sluzhba statystyky Ukrai'ny (2021), Robocha syla Ukrai'ny 2020, statystychnyj zbirnyk, [Online], available at: http://www.ukrstat.gov.ua/druk/publicat/kat_u/2021/zb/07/zb_r_s_2020.xlsx

11. Derzhavna sluzhba statystyky Ukrai'ny (2020), Robocha syla Ukrai'ny 2019, statystychnyj zbirnyk, [Online], available at: http://www.ukrstat.gov.ua/druk/publicat/kat_u/2020/zb/07/zb_r_s_2019.pdf

12. Romanova, T.V. (2016), «Integral'ni pokaznyky ocinjuvannja strukturnyh zrushen' v ekonomici», Ekonomika $i$ region, No. 6 (61), pp. 20-27.

13. Zhalilo, Ja.A., Bazyljuk, Ja.B., Kovalivs'ka, S.V. et al. (2020), Ukrai'na pislja koronakryzy: shljah oduzhannja, NISD, Kyi'v, 304 p., [Online], available at: https://niss.gov.ua/sites/default/files/2020-11/ukraina-pislyakoronakrizi_sait.pdf

14. Shtunder, I.O. (2016), Efektyvna zajnjatist': realii' ta innovacijni perspektyvy, monografija, Universytet ekonomiky ta prava «KROK», Kyi'v, 392 p.

15. Pavelescu, F.M. (2014), «Methodological considerations on the size of Coefficient of Intensity of Structural Changes», Revista Română de Statisticăa, Vol. 62 (2), pp. 95-107, [Online], available at: https://ideas.repec.org/a/rsr/journl/v62y2014i2p95-107.html\#download

Лісогор Лариса Сергіївна - доктор економічних наук, професор, головний науковий співробітник сектору регіональних стратегій центру регіональних досліджень Національного інституту стратегічних досліджень.

https://orcid.org/0000-0001-5624-597X.

Наукові інтереси:

- проблеми ринку праці, зайнятості;

- основні тенденції змін регіональної зайнятості;

- конкурентоспроможність робочої сили, освіта та професійна підготовка.

E-mail: laralisogor@gmail.com.

Руденко Наталя Валентинівна - кандидат економічних наук, доцент кафедри міжнародної економіки та маркетингу Київського національного університету імені Тараса Шевченка.

https://orcid.org/0000-0003-0939-8206.

Наукові інтереси:

- проблеми зайнятості, глобального розвитку;

- проблеми національного та регіональних ринків праці;

- освіта та кваліфікації у сучасному світі.

E-mail: nataly777555@ukr.net. 